\title{
Relationship between Leaf Photosynthesis and Nitrogen Content of Field-Grown Rice in Tropics
}

\author{
Shaobing Peng,* Kenneth G. Cassman, and Martin J. Kropff
}

\begin{abstract}
A field-derived relationship between maximum single leaf net photosynthetic rate under saturating light $\left(A_{\max }\right)$ and leaf $\mathrm{N}$ content per unit leaf area $\left(\mathrm{N}_{\mathrm{g}}\right)$ is not available for rice (Oryza sativa L.). The rice simulation model ORYZA1 estimates aboveground dry matter production based on the relationship between $A_{\max }$ and $\mathrm{N}_{\mathrm{a}}$ determined previously under greenhouse-growth chamber conditions. The objectives of this study were to establish to relationship between $A_{\max }$ and $N_{a}$ under field conditions and to determine whether the field-derived relationship could improve ORYZAl estimation of aboveground dry matter production of tropical irrigated rice. Rice plants were grown in the field with different $N$ rates in the 1993 dry season. The $A_{\max }$ and $N_{a}$ were determined at 38 and $88 \mathrm{~d}$ after transplanting. Aboveground dry matter was determined at physiological maturity. Dry matter production data at physiological maturity from four other field experiments were used for model evaluation. There was a close correlation between $A_{\max }$ and $\mathrm{N}_{\mathrm{a}}$ under field conditions $\left(r^{2}=0.88\right)$. Compared with the relationship between $A_{\max }$ and $\mathrm{N}_{\mathrm{n}}$ as determined under greenhouse-growth chamber conditions in previous studies, higher $A_{\mathrm{max}}$ was observed at low $\mathrm{N}_{\mathrm{a}}$ in this field study. When the field-derived relationship between $A_{\max }$ and $\mathrm{N}_{\mathrm{a}}$ was used, ORYZA1 estimation of dry matter production was improved for rice grown in tropical irrigated environments.
\end{abstract}

$\mathrm{T}$ HERE IS a close relationship between maximum leaf photosynthetic rate under saturating light $\left(A_{\max }\right)$ and leaf $\mathrm{N}$ content in many plant species (Field and Mooney, 1986). This relationship has been reported to be linear or curvilinear in different studies on rice. Mitsui and Ishii $(1938,1939)$ first reported that $A_{\max }$ was linearly correlated with leaf $\mathrm{N}$ concentration per unit dry weight $\left(\mathrm{N}_{\mathrm{dw}}\right)$ between 32.6 and $64.2 \mathrm{~g} \mathrm{~N} \mathrm{~kg}^{-1}(r=0.84)$. Other studies also reported a linear relationship between $A_{\max }$ and leaf $\mathrm{N}$ content per unit leaf area $\left(\mathrm{N}_{\mathrm{i}}\right)$ (Osada, 1967; Yoshida and Coronel, 1976; Uchida et al., 1982; Cook and Evans, 1983a; Makino et al., 1988). On the other hand, a curvilinear relation between $A_{\max }$ and $\mathrm{N}_{\mathrm{a}}$ was reported by Murata (1961), Takano and Tsunoda (1971), and Cook and Evans (1983b) in rice lines with diverse genetic origins. In these studies, a linear relationship between $A_{\max }$ and $\mathrm{N}_{\mathrm{a}}$ was found below $1.6 \mathrm{~g} \mathrm{~N} \mathrm{~m}^{-2}$, but $A_{\text {max }}$ leveled off above $1.6 \mathrm{~g} \mathrm{~N} \mathrm{~m}^{-2}$.

A rice simulation model for irrigated ecosystems, ORYZA 1, was developed jointly by the Int. Rice Research Inst. (IRRI) and Wageningen Agricultural Univ. (Kropff et al., 1994). In this model, $A_{\max }$ is calculated from $\mathrm{N}_{\mathrm{a}}$ and average daytime air temperature. Daily $\mathrm{CO}_{2}$ assimilation of the canopy is calculated based on $A_{\max }$, leaf $\mathrm{N}$ profile in the canopy, light distribution in the canopy, and leaf area index. The net daily crop growth

Agronomy, Plant Physiology, and Agroecology. Division, Int. Rice Re search Inst., P.O. Box 933, Manila 1099, Philippines. Contribution from IRRI. Received 4 Jan. 1995. *Corresponding author (speng.@irri. cgnet.com).

Published in Crop Sci. 35:1627-1630 (1995). rate is obtained from daily $\mathrm{CO}_{2}$ assimilation after subtracting respiration requirements. The ORYZAl (Version 1) underestimates dry matter production of tropical irrigated rice when the observed dry matter production is low. Low dry matter production is often caused by low solar radiation, such as in the wet season, and low leaf $\mathrm{N}$ content at later growth stages.

It is hypothesized that the greenhouse-derived relationship between $A_{\max }$ and $\mathrm{N}_{\mathrm{a}}$ is mainly responsible for the underestimation with ORYZAI of dry matter production. The relationship between $A_{\max }$ and $\mathrm{N}_{\mathrm{a}}$ used in the ORYZA1 was established based on data from many species, such as beet (Beta vulgaris L.), rice, soybean [Glycine max (L.) Merr.], and wheat (Triticum aestivum L.) (van Keulen and Seligman, 1987). Most studies on the relationship between $A_{\max }$ and leaf $\mathrm{N}$ were based on pot-grown plants with soil or culture solution under greenhouse-growth chamber conditions, and $A_{\max }$ was often determined under artificial light provided by incandescent lamps (Nevins and Loomis, 1970; Yoshida and Coronel, 1976; Cook and Evans, 1983a; Evans, 1983; Makino et al., 1988). Field conditions in the tropics, however, differ greatly from greenhouse or chamber environments in terms of light level and quality, temperature, and humidity. These may cause different growth and development characteristics between plants grown in the field and in the greenhouse-growth chambers. In this study, we measured $A_{\max }$ and $\mathrm{N}_{\mathrm{a}}$ of field-grown rice plants with a portable photosynthesis system. The objectives of this study were to determine the relationship between $A_{\max }$ and $\mathrm{N}_{\mathrm{a}}$ under tropical field conditions and to test whether the field-derived relationship could improve ORYZA l estimation of dry matter production of tropical irrigated rice.

\section{MATERIALS AND METHODS}

A field experiment was conducted in the 1993 dry season (January-April) at the IRRI, Los Baños, Philippines. The soil was an Andaqueptic Haplaquoll with pH $6.0,16.2 \mathrm{~g}$ organic $\mathrm{C} \mathrm{kg}^{-1}, 1.5 \mathrm{~g}$ total $\mathrm{N} \mathrm{kg}^{-1}$, and $32.9 \mathrm{cmol} \mathrm{kg}^{-1}$ cation-exchange capacity. Treatments were arranged in a split-plot design with four replicates. Main plots were different $\mathrm{N}$ fertilizer levels and subplots consisted of either the indica inbred IR72 or a new tropical indica $F_{1}$ hybrid IR64616H (Table 1). Nitrogen levels were $0,45,120,165,180$, and $225 \mathrm{~kg} \mathrm{ha}^{-1}$ as prilled urea. All plots received $18 \mathrm{~kg} \mathrm{P} \mathrm{ha}^{-1}$ as single superphosphate and $33 \mathrm{~kg} \mathrm{~K}^{-1}$ as $\mathrm{KCl}$ incorporated before transplanting. Fourteen-day-old seedlings were transplanted on 12 Jan. at a hill spacing of 0.2 by $0.2 \mathrm{~m}$ with five plants per hill. Subplot dimensions were 5 by $6 \mathrm{~m}$.

Single leaf net photosynthetic rates were measured with a portable photosynthesis system (LI-6200, LI-COR, Lincoln, NE). To ensure light saturation, $A_{\max }$ was measured between

Abbreviations: IRRI, Int. Rice Research Inst.; DAT, days after transplanting; PAR, photosynthetically active photon flux. 
Table 1. Field experiments conducted in the International Rice Research Institute (IRRI), Los Baños, Laguna, and the Philippine Rice Research Institute (PhilRice), Muñoz, Nueva Ecija, the Philippines.

\begin{tabular}{|c|c|c|c|c|}
\hline Year & \multicolumn{2}{|c|}{ Season Location } & \multirow[t]{2}{*}{ Variety } & \multirow[t]{2}{*}{ Fertilizer $N$ level } \\
\hline & & & & \\
\hline 1991 & Wet & IRRI & IR72, IR59109-113-3-3-2 & $0,80,110$ \\
\hline 1992 & Dry & IRR I & $\begin{array}{l}\text { IR72, IR59109-113-3-3-2, } \\
\text { IR } 64616 \mathrm{H}\end{array}$ & $0,100,180,225$ \\
\hline 1992 & Wet & IRRI & $\begin{array}{l}\text { IR72, IR58185-23-3-3-1, } \\
\text { IR64616H }\end{array}$ & $0,30,80,110$ \\
\hline 1993 & Dry & IRRI & IR72, IR64616H & $0,45,120,165,180,225$ \\
\hline 1993 & Dry & PhilRice & IR72, IR64616H & $0,45,120,165,180,225$ \\
\hline
\end{tabular}

1000 and $1300 \mathrm{~h}$ at 38 and $88 \mathrm{~d}$ after transplanting (DAT) when the photosynthetically active photon flux (PAR) was between 1800 and $2000 \mu \mathrm{mol} \mathrm{m} \mathrm{m}^{-2} \mathrm{~s}^{-1}$. A $0.25-\mathrm{L}$ chamber was used to enclose the middle portion of the uppermost fully expanded leaf. Four leaves from each plot of three replicates were selected for the measurements. The gas exchange system was operated as a closed system to measure photosynthetic rate during a $20-\mathrm{s}$ period. After the measurement of $A_{\max }$, the leaf was detached and area, dry weight, and total $\mathrm{N}$ were determined for each entire leaf blade. Area was measured with a leaf area meter (LI-3000, LI-COR). Dry weight was determined after oven-drying at $70^{\circ} \mathrm{C}$ to constant weight. Total leaf $\mathrm{N}$ was determined on the entire leaf blade by micro Kjeldahl digestion and distillation (Bremner and Mulvaney, 1982). Leaf $N$ content was expressed on a leaf area basis.

A rice stimulation model, ORYZAl (Kropff et al., 1994), was used to simulate aboveground dry matter production of varieties and $\mathrm{N}$ fertilizer levels in five field experiments (Table 1). The four other field experiments had the same experimental design as the experiment conducted in the 1993 dry season at IRRI. Grain yield was determined from a $5-\mathrm{m}^{2}$ harvest area at physiological maturity. Harvest index was determined from a $0.5-\mathrm{m}^{2}$ harvest area at the same time as grain yield. Aboveground dry matter production was calculated from grain yield and harvest index. Separate simulations were run with the regression equations between $A_{\max }$ and $\mathrm{N}_{\mathrm{a}}$ reported by van Keulen and Seligman (1987) or as derived from this study. The input requirements of the model were daily weather data (total radiation and minimum and maximum air temperatures), plant spacing, and date of crop emergence and transplanting. The simulated dry matter production was compared with actual values by linear correlation.

\section{RESULTS AND DISCUSSION}

The relationship between $A_{\max }$ and $\mathrm{N}_{\mathrm{a}}$ was not significantly different from IR72 and IR64616 H at 38 and 88 DAT. Therefore, all data were pooled in Fig. 1. There was a close correlation between $A_{\max }$ and $\mathrm{N}_{\mathrm{a}}$. The $A_{\max }$ was linearly related to $\mathrm{N}_{\mathrm{a}}$ within the observed range of $\mathrm{N}_{\mathrm{a}}$ :

$$
A_{\text {max }}=6.00+14.20 \mathrm{~N}_{\mathrm{a}}
$$

van Keulen and Seligman (1987) reported a generic relationship between $A_{\text {nax }}$ and $\mathrm{N}_{\mathrm{a}}$ based on the data from beet, rice, maize, and wheat:

$$
A_{\max }=-4.10+20.45 \mathrm{~N}_{\mathrm{a}}
$$

Equation [2] is similar to the equations of Yoshida and Coronel (1976) and Makino et al. (1988) for rice (Fig. 2). Most studies indicated a linear relationship when $N_{a}$

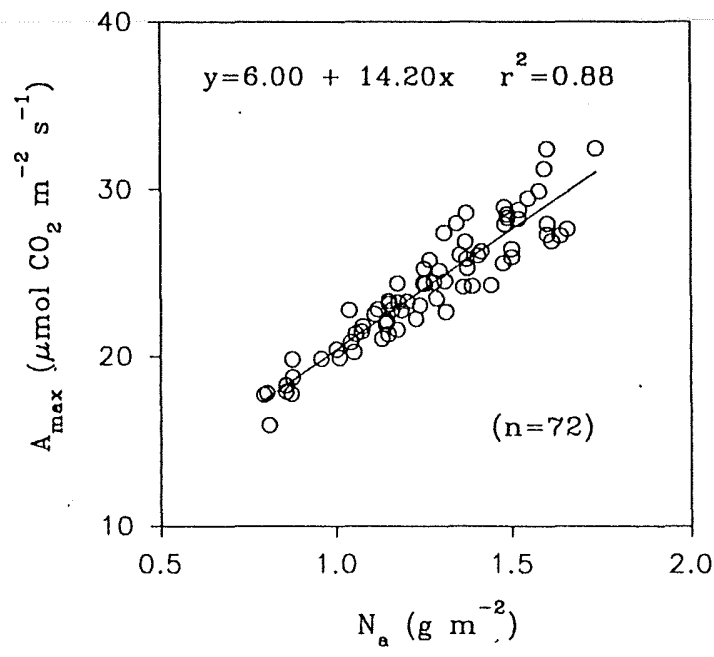

Fig. 1. Relationship between light-saturated single leaf photosynthetic rate $\left(A_{\operatorname{mas}}\right)$ and leaf $N$ content on a leaf area basis $\left(N_{n}\right)$ of IR72 and IR64616H at 38 and 88 d after transplanting, 1993 dry season, at Int. Rice Research Inst., Los Baños, Philippines. Each data point is the mean of four subsamples.

ranges from 0.5 to $2.1 \mathrm{~g} \mathrm{~m}^{-2}$. The curvilinear response used by Sinclair and Horie (1989) was based on the data of Takano and Tsunoda (1971) in which $A$ and $\mathrm{N}_{\mathrm{a}}$ were determined on 40 rice lines from diverse genetic origins. This curvilinear relationship might have resulted from growth limitations in some of the genotypes by factors other than leaf $\mathrm{N}$, which in turn may have influenced the relationship between $A_{\max }$ and $\mathrm{N}_{\mathrm{a}}$.

Most of the studies on the relationship between $A_{\max }$ and $\mathrm{N}_{\mathrm{a}}$ were conducted in pots with soil or solutionculture systems under greenhouse-growth chamber conditions (Table 2), probably due to unavailability of a portable photosynthesis system. The relationship be-

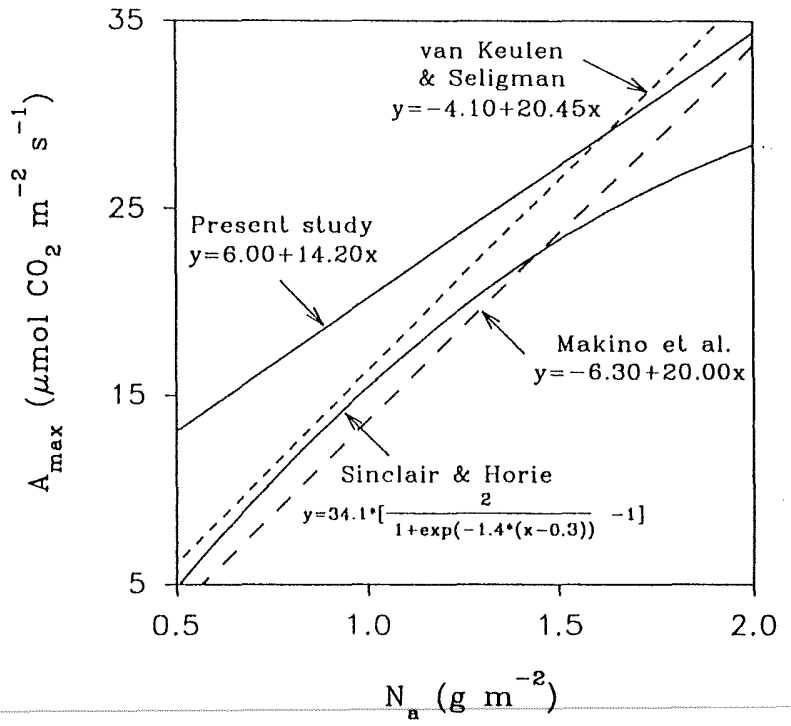

Fig. 2. Comparison of relationships between light-saturated single leaf photosynthetic rate $\left(A_{\max }\right)$ and leaf $N$ content on a leaf area basis $\left(N_{n}\right)$ reported by van Keulen and Seligman (1987), Makino et al. (1988), and Sinclair and IIorie (1989) and determined in this study. 
Table 2. Cultural conditions of rice plants, light level, and light source when photosynthetic rates were measured for the studies on the relationship between photosynthetic rate and leaf $N$ content.

\begin{tabular}{|c|c|c|c|c|}
\hline Author & Year & Culture conditions & Light level & Light source \\
\hline Mitsui and Ishii & 1938 & greenhouse, solution & -1 & - \\
\hline Mitsui and Ishii & 1939 & pot with soil & 27 klux (527) $\ddagger$ & - \\
\hline Murata & 1961 & solution & 50 klux $(977)^{+}$ & - \\
\hline Takano and Tsunoda & 1971 & greenhouse, soil & 85 klux (1660) & incandescent lamps \\
\hline Yoshida and Coronel & 1976 & solution & - & - \\
\hline Uchida et al. & 1982 & greenhouse, solution & 70 klux (1367) & - \\
\hline Cook and Evans & $1983 a$ & phytotron, soil & $800 \S$ & incandescent lamps \\
\hline Makino et al. & 1988 & phytotron, solution & . $\quad 1800 \S$ & incandescent lamps \\
\hline Present study & 1994 & field & $1800-2000 \S$ & full sunlight \\
\hline
\end{tabular}

+ Information not available.

$\ddagger$ Only illumination unit (kilolux) was provided. Numbers in parentheses were converted from kilolux to $\mu$ mol photon $\mathrm{m}^{-2} \mathrm{~s}^{-1}$ Iphotosynthetically active photon flux (PAR)] assuming $1 \mathrm{klux}=19.53 \mu \mathrm{mol}$ photon $\mathrm{m}^{-2} \mathrm{~s}^{-1}$.

$\S \mu$ mol photon $\mathrm{m}^{-2} \mathrm{~s}^{-1}$ (PAR).

tween $A_{\max }$ and $\mathrm{N}_{\mathrm{a}}$ determined under tropical field conditions in this study was different from previously reported relationships (Fig. 2). The field-derived equation indicates a higher $A_{\max }$ at low leaf $\mathrm{N}$ values, especially at $\mathrm{N}_{\mathrm{a}}<1 \mathrm{~g} \mathrm{~m}^{-2}$ compared with other equations. In the 1992 dry season, $A_{\max }$ and $\mathrm{N}_{\mathrm{a}}$ were measured on 16 flag leaves at mid-grain filling. Average $\mathrm{N}_{\mathrm{a}}$ was $1.00 \pm 0.03$ (standard deviation) $\mathrm{g} \mathrm{m}^{-2}$ and average $A_{\max }$ was $19.5 \pm$ $0.8 \mu \mathrm{mol} \mathrm{m}^{-2} \mathrm{~s}^{-1}$. Calculated $A_{\max }$ based on Eq. [1] was 20.2 , which was close to the observed value. Calculated $A_{\max }$ based on Eq. [2] was 16.4 , which was $16 \%$ lower than the observed value. The discrepancy between Eq. [1] and [2] may be due to the differences in species and/ or in plant growth and development caused by different light levels and quality, temperature, and humidity between greenhouse-growth chamber and tropical field conditions. Potted plants may also grow differently from field-grown plants because of root restriction. Gas exchange measurement techniques were previously not available or not adaptable to permit accurate determination of leaf photosynthetic rate under field conditions. Within the past few years, stable and miniature infrared $\mathrm{CO}_{2}$ gas analyzers have been developed and incorporated into portable photosynthesis systems such as the LI-6200 used in this study. Although Eq. [1] was based on data from only one season, photosynthesis measurements were determined on 288 leaves (means of four subsamples were used in Fig. 1) of two varieties at two growth stages. Relationships between $A_{\max }$ and $\mathrm{N}_{\mathrm{a}}$ reported ear-

Table 3. Observed and simulated dry matter production of five field experiments (Table 1) using the rice simulation model ORYZA1. The regression equations between light saturated single leaf photosynthetic rate $\left(A_{\max }\right)$ and leaf $\mathrm{N}$ content on a leaf area basis $\left(\mathrm{N}_{\mathrm{a}}\right)$ developed by van Keulen and Seligman (1987) and derived from this study were used in the ORYZA1, respectively.

\begin{tabular}{|c|c|c|c|c|}
\hline Group & $\begin{array}{c}\text { Number of } \\
\text { observations }\end{array}$ & $\begin{array}{l}\text { Observed } \\
\text { value }\end{array}$ & $\begin{array}{c}\text { Simulated } \\
\text { with } \\
\text { Eq. [1]† }\end{array}$ & $\begin{array}{c}\text { Simulated } \\
\text { with } \\
\text { Eq. }[2] \dagger\end{array}$ \\
\hline & & & $-\mathrm{h} \mathrm{ha} \mathrm{s}^{-1}$ & \\
\hline $\begin{array}{l}\text { Less than } 15 \mathrm{tha}^{-1} \\
\text { More than } 15 \mathrm{t} \mathrm{ha}^{-1}\end{array}$ & $\begin{array}{l}30 \\
24\end{array}$ & $\begin{array}{r}9.9 \\
17.6\end{array}$ & $\begin{array}{l}9.7(-2) \ddagger \\
17.9(2)\end{array}$ & $\begin{array}{l}8.9(-10) \\
17.6(0)\end{array}$ \\
\hline
\end{tabular}

+ Equation [1] = relationship between $A_{\max }$ and $N_{a}$ derived from this study Equation [2] = relationship between $A_{\max }$ and $N_{a}$ developed by van Keulen and Seligman (1987).

$¥$ Numbers in parentheses are the percentages of difference from the observed value. lier were based on only a few data points determined at one growth stage.

Aboveground dry matter production of treatments in the five field experiments were separately simulated with ORYZA1 using Eq. [1] and [2]. With both equations, the model accurately estimated dry matter production in treatments that had dry matter accumulation $>15 \mathrm{t} \mathrm{ha}^{-1}$ (Table 3). In contrast, both simulation models underestimated dry matter in the treatments with dry matter accumulation $<15 \mathrm{t} \mathrm{ha}^{-1}$, but the estimation was improved by using Eq. [1] compared with Eq. [2] (Table 3; Fig. 3). With Eq. [2], ORYZA1 underestimated dry matter by $10 \%$ but only by $2 \%$ with Eq. [1]. Average canopy $\mathrm{N}_{\mathrm{a}}$ of treatments with low dry matter levels was generally lower than that with high dry matter levels (e.g., 1.1 vs. $1.3 \mathrm{~g} \mathrm{~N} \mathrm{~m}^{-2}$ at flowering in the 1992 dry season experiment). Therefore, using the greenhouse-derived equation between $A_{\max }$ and $\mathrm{N}_{\mathrm{a}}$ underestimates $A_{\max }$ of low $\mathrm{N}$ leaves of field-grown rice plants in the tropical environments and results in greater underestimation of

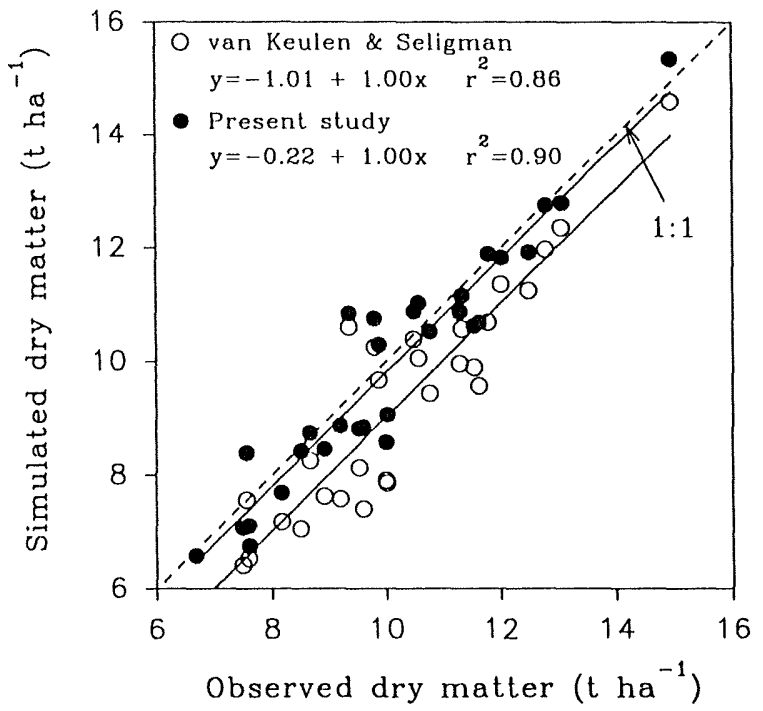

Fig. 3. Comparison between observed $\left(<15, \mathrm{ha}^{-1}\right)$ and simulated aboveground dry matter production of treatments in five field experiments (Table 1) with the rice simulation model ORYZA1. The regression equations between light-saturated single leaf photosynthetic rate $\left(A_{\max }\right)$ and leaf $\mathrm{N}$ content on a leaf area basis $\left(\mathrm{N}_{\mathrm{n}}\right)$ developed by van Keulen and Seligman (1987) and derived from this study were used in the ORYZA1 simulations. 
dry matter production of tropical irrigated rice by the simulation model ORYZA1 than when the equation is used that was developed in this study.

In conclusion, the field-derived relationship between $A_{\max }$ and $\mathrm{N}_{\mathrm{a}}$ of tropical irrigated rice was significantly different from those previously determined under greenhouse-growth chamber conditions, especially in the low $\mathrm{N}_{\mathrm{a}}$ range. The field-derived relationship improves the estimation of dry matter production of tropical irrigated rice by the rice simulation model ORYZA1.

\section{ACKNOWLEDGMENTS}

We thank the Philippine Rice Research Institute for providing us excellent facilities for conducting the field experiments; Drs. G.S. Khush and S.S. Virmani for providing us the inbred the $F_{1}$ hybrid seeds; and S. Liboon, R.C. Laza, and F.V. Garcia for their technical assistance in managing the field experiment, measurements, and data collection.

\section{REFERENCES}

Bremner, J.M., and C.S. Mulvaney. 1982. Nitrogen - total. p. 595624. In A.L. Page et al. (ed.) Methods of soil analysis. Part 2. 2nd ed. Agron. Monogr. 9. ASA and SSSA, Madison, WI.

Cook, M.G., and L.T. Evans. 1983a. Nutrient responses of seedlings of wild and cultivated Oryza species. Field Crops Res, 6:205218.

Cook, M.G., and L.T. Evans. 1983b. Some physiological aspects of the domestication and improvement of rice (Oryza spp.). Field Crops Res. 6:219-238.

Evans, J.R. 1983. Nitrogen and photosynthesis in the flag leaf of wheat (Triticum aestivum L.). Plant Physiol. 72:297-302.

Field, C., and H.A. Mooney. 1986. The photosynthesis-nitrogen relationship in wild plants. p. 25-55. In T.J. Givnish (ed.) On the economy of plant form and function. Cambridge University Press, Cambridge, UK.

Kropff, M.J., H.H. van Laar, and R.B. Matthews. 1994. ORYZAI: An ecophysiological model for irrigated rice production. p. 1326. SARP Research Proceedings. Research Inst. for Agrobiology and Soil Fertility, Wageningen, the Netherlands, and Int. Rice Research Institute, Los Baños, Philippines.

Makino, A., T. Mae, and K. Ohira. 1988. Differences between wheat and rice in the enzymic properties of ribulose-1,5-bisphosphate carboxylase/oxygenase and the relationship to photosynthetic gas exchange. Planta 174:30-38.

Mitsui, S., and Y. Ishii. 1938. Effects of supply of three major nutrients on photosynthetic rate of rice seedlings. J. Sci. Soil Manure Jpn. 12:287-289.

Mitsui, S., and Y. Ishii. 1939. Effects of nitrogen top-dressing on photosynthetic activity of the rice plant. J. Sci. Soil Manure Jpn. 13:309-313.

Murata, Y. 1961. Studies on the photosynthesis of rice plants and its cultural significance. Bull. Natl. Inst. Agric. Sci. Ser. D: Plant Physiol. Genet. Crops Gen. 9:1-170.

Nevins, D.J., and R.S. Loomis. 1970. Nitrogen nutrition and photosynthesis in sugar beet (Beta vulgaris L.). Crop Sci. 10:21-25.

Osada, A. 1967. Relationship between photosynthetic activity and dry matter production in rice varieties, especially as influenced by nitrogen supply. Bull. Natl. Inst. Agric. Sci. Ser. D: Plant Physiol. Genet. Crops Gen. 14:117-188.7.

Sinclair, T.R., and T. Horie. 1989. Leaf nitrogen, photosynthesis, and crop radiation use efficiency: A review. Crop Sci. 29:90-98.

Takano, Y., and S. Tsunoda. 1971. Curvilinear regression of the leaf photosynthetic rate on leaf nitrogen content among strains of Oryza species. Jpn. J. Breed. 21:69-76.

Uchida, N., Y. Wada, and Y. Murata. 1982. Studies on the changes in the photosynthetic activity of a crop leaf during its development and senescence. II. Effect of nitrogen deficiency on the changes in the senescing leaf of rice. Jpn. J. Crop Sci. 51:577-583.

van Keulen, H., and N.G. Seligman. 1987. Plant growth processes. p. 48. In Simulation of water use, nitrogen and growth of a spring wheat crop. PUDOC, Wageningen, the Netherlands.

Yoshida, S., and V. Coronel. 1976. Nitrogen nutrition, leaf resistance, and leaf photosynthetic rate of the rice plant. Soil Sci. Plant Nutr. (Tokyo) 22(2):207-211. 